\title{
DIGITAL ENGINEERING GEOLOGICAL MAP OF THE ATHENS PREFECTURE AREA AND RELATED DATABASE MANAGEMENT SYSTEM
}

\author{
Kynigalaki M. ${ }^{1}$, Nikolaou N. ${ }^{1}$, Karfakis J. ${ }^{1}$, Koutsouveli An. ${ }^{1}$, Poyiadji El. ${ }^{1}$, \\ Pyrgiotis L. ${ }^{1}$, Konstantopoulou G. ${ }^{1}$, Bellas M. ${ }^{1}$, Apostolidis Em. ${ }^{1}$, Loupasakis \\ K. ${ }^{1}$, Spanou N. ${ }^{1}$, Sabatakakis N. ${ }^{2}$ and Koukis G. ${ }^{2}$ \\ ${ }^{1}$ IGME / Engineering Geology Dpt., Entrance C, 1 Sp. Louis St, Olympic Village, 13677 Acharnae, Athens, \\ Greecenikolaou@igme.gr \\ ${ }^{2}$ University of Patras, Department of Geology, Laboratory of Engineering Geology, 26500 Patras, Greece, \\ g.koukis@upatras.gr
}

\begin{abstract}
A digital engineering-geological map of the Athens Prefecture area was compiled at an original scale of 1:10.000 by IGME in cooperation with Engineering Geology Laboratory of Patras University. The map is related to a database management system constructed according to the project's special needs, including geotechnical and geological data mainly obtained by boreholes and trial pits. The main map (11 sheets) is accompanied by three thematic maps at an original scale 1:50.000 (hydrogeological, tectonic) and 1:250.000 (seismic epicenters map). It constitute a basic tool for every activity of the Prefecture's services, in relation to urban development, civil and environmental protection policy, sustainable management of natural resources, continual data supply to citizens and to the technical world.

The main advantage of the digital map is the ability of constant updating of the related database, while this procedure should be established to serve social needs. As the mapping was based on a combination of conventional geological mapping techniques and the information from geotechnical database, it is considered to provide useful information for planners and decision makers at a preliminary planning level.
\end{abstract}

Key words: engineering geological mapping, data base, urban development, Athens Prefecture.

\section{Introduction}

The urban planning of the city of Athens was primarily based on economic and social determinants, without taking seriously into account the geological environment and the geodynamic factor. The problems that have been arisen due to this became more acute with the increase of the population and urban settlement expansion, the industrialization and the natural hazard impact (seismicity, floods) during the last decades. With the increasing demand for large engineering works construction (subways, freeways, metro, traffic links), the redevelopment of the broader area and the reconstruction of the inner city area, there was a need for up to date geological information and interpretation for planning purposes. 


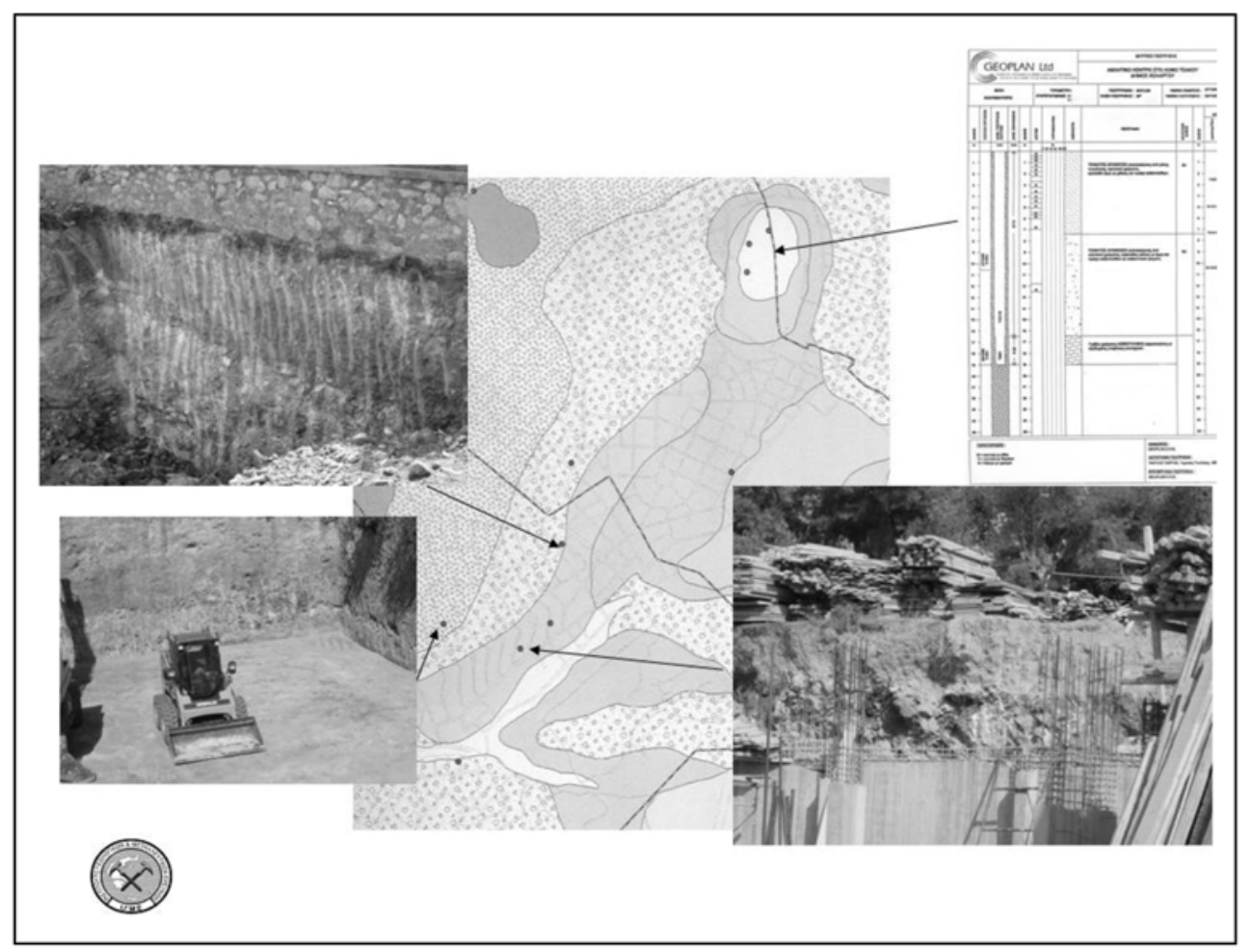

Fig.1: Part of a map sheet, accompanied by the relative information (excavation photos and borehole logs), introduced into the data base.

The geological, hydrogeological and geotechnical conditions prevailing the urban area must be generally well known for providing the necessary information to the local authorities, engineers and constructors, since they consist the framework for technical works planning. This information also constitutes the basic concept for the evaluation of the dynamic ground response in the case of seismic activity.

The IGME in cooperation with the University of Patras (Department of Geology - Laboratory of Engineering Geology), were commissioned to undertake the compilation of the digital engineering geological map of Athens Prefecture area at a scale of 1:10.000. The outcome (Fig. 1) was eleven (11) map sheets that cover the studied area (45 Municipalities and 3 Communities), accompanied by an extended legend and three (3) attached thematic digital maps, at various scales, as well as the relative data base. The work was coordinated by the Engineering Geology Department of IGME, while other Departments of IGME also collaborated for the creation of thematic maps, such as that of Geology and Geological Mapping Dept, as well as the Department of Hydrogeology.

\section{Aims of the Project - The digital engineering geological map}

In order to give a detailed description of engineering geological environment of the studied area, the working group placed the following objectives:

1. Digital management of the available geological and engineering geological information in the region of interest. 
2. Relocation of the gathered information in a map of 1:10.000 scale with respect to the suitable accuracy.

3. Collection and handling of data, so that to obtain as possible homogeneity, density and reliability in geological - engineering geological information, all over the mapped area.

4. Reconsideration of configured information and update, according to the additional geological - engineering geological data obtained by the groups and companies involved in the area's recent constructional activity.

5. Digital recording of a satisfactory number of borehole data in the created database obtained by public organizations and private consultants.

The engineering geological map compilation and the database creation, in combination with the attached set of thematic maps are considered to fulfil the engineering geological demands of Athens Prefecture responsibilities. More specifically it can constitute the basic tool for:

- Urban planning of infrastructure developmental works

- Mitigation of natural hazards and improvement of citizens' safety

- Protection and upgrade of the environment

- Sustainable management of natural resources

- Citizens' awareness

- Optimum exploitation of technical knowledge for advanced quality of life

It is pointed out that the information and data presented in an engineering geological map at 1:10.000 scale, does not substitute the site geotechnical investigation required for technical work constructions. Consequently, it does not withdraw the existing legal frame for public and private works, but offers guidance and technical support.

Moreover the advantage of digital maps is the continuous data updating which is strongly recommended to be established by the authorities in charge. Digital parameters also allow useful applications to be carried out, such as correlations, zonation, retrieval of selected data etc.

The topographic background of the engineering geological map at 1:10.000 scale was created from the digital background provided by the Prefecture of Athens, using Geographical Information Systems and more specifically ArcGIS 9.0. It has been produced with the accuracy of 1:5.000 scale map and it includes, apart from the road network, also the boundaries of 45 Municipalities and 3 Communities that belong to the Prefecture of Athens.

For the creation of digital data, the official Greek projection system (EGSA 87) has been used.

In order to obtain an accurate and up to date engineering geological map, the boundaries of the configurated formations have been redrawn in the field. For this aim two main bibliographic sources have been implemented as guides, namely:

a) the engineering geological maps at a scale of 1:25.000 of PhD thesis of N. Sabatakakis (1991), entitled "Engineering geological research of Athens Basin" (University of Patras), as well as

b) the Geological maps of the Institute of Geology and Mineral Exploration at 1:50.000 scale, sheets “ATHINAI - PIRAEUS”, “ATHINAI - ELEFSIS", “KIFISSIA” and "KOROPI - PLAKA".

\section{Legend of the engineering geological map}

To describe in detail the engineering geological conditions of the urban area of the city the soil formations were grouped into twenty (20) individual geotechnical units, based on the evaluation of ex- 
isting geotechnical database and the origin, relevant age, composition, physical state and engineering geological characteristics of the ground formations. In the full text description of each unit the particular characters of macroscopic observation are given, as well as qualitative and quantitative parameters from laboratory tests.

It is pointed out that the range of the given parameters has an indicative character and was determined by the bibliography of the wider area, as well as the selected studies of the Athens Prefecture area, that have been imported in the data base.

Finally, the classification of the engineering geological formations according to the Greek Seismic Regulation (E.A.K. - 2000) is also given in the legend.

A summarized description of soil units is given bellow:

\begin{tabular}{|c|c|}
\hline 1. & Man-made fill material. \\
\hline 2. & Recent materials of rivers, streams and coastal beds. \\
\hline 3. & Loose coastal deposits of grey sandy silts and soft clays. \\
\hline 4. & Loose deposits of mixed phases with predominance of fine materials \\
\hline 5. & Loose deposits of mixed phases with predominance of coarse materials. \\
\hline 6. & Scree materials moderately to well cemented. \\
\hline 7. & Moderately cemented breccia-conglomerates with brown-reddish cementing material. \\
\hline 8. & Semi-cohesive silts - clays of light brown colour \\
\hline 9. & $\begin{array}{l}\text { Semi-cohesive to cohesive formations of thin layers of sandstones, micro-conglomerates, } \\
\text { conglomerates and sands of marine facies, sub-white in colour. }\end{array}$ \\
\hline 10. & Cohesive red loams and moderately cemented conglomerates. \\
\hline 11. & $\begin{array}{l}\text { Semi-cohesive to very cohesive formations of marls, sandstones, marly limestones, yel- } \\
\text { low-white in colour. }\end{array}$ \\
\hline 12. & Medium to thick bedded, intensely fissured, white-grey limestones of allochthonous series. \\
\hline 13. & Thin to medium bedded limestones, strongly tectonised, of yellow to white colour. \\
\hline 14. & Thick-bedded to massive, strongly tectonised and karstified limestones. \\
\hline 15. & Dolomites - dolomitic limestones. \\
\hline 16. & Schist-sandstone-marly series of the Athenian schists with limestone lenses. \\
\hline 17. & Athenian schists. \\
\hline 18. & Marlbles with schist layers. \\
\hline 19. & Schists with marble layers. \\
\hline 20. & Semi-metamorphic to metamorphic undivided formations. \\
\hline
\end{tabular}

The physical and mechanical properties that are given in the full text legend of the engineering geological map are the following:

Soils: LL (\%), IP (\%), w (\%), $\gamma_{\mathrm{b}}\left(\mathrm{t} / \mathrm{m}^{3}\right), \mathrm{e}, \mathrm{N}_{\mathrm{SPT}}, \mathrm{q}_{\mathrm{u}}(\mathrm{kPa}), \mathrm{C}_{\mathrm{c}}, \mathrm{c}_{\mathrm{u}}(\mathrm{kPa}), \phi_{\mathrm{u}}\left(^{\circ}\right)$.

Rocks: $\varrho_{d}\left(\mathrm{kN} / \mathrm{m}^{3}\right), \sigma_{\mathrm{c}}(\mathrm{MPa}), \sigma_{\mathrm{t}}(\mathrm{MPa}), \mathrm{I}_{\mathrm{s}(50)}(\mathrm{MPa}), \mathrm{E}_{\mathrm{L}}(\mathrm{GPa}), \mathrm{n}(\%), \mathrm{V}_{\mathrm{P}}(\mathrm{m} / \mathrm{sec}), \mathrm{I}_{\mathrm{d} 2}(\%), v, \mathrm{SHV}$ 


\section{Atlas of thematic maps}

A set of thematic maps was also compiled attached to the engineering geological map of 1:10.000 scale. Each map was drawn in particular individual scale according to the character of the special information shown. More specifically these maps are:

\subsection{Hydrogeological map}

Since the hydrogeological conditions constitute an important factor affecting the geotechnical behaviour of geological formations, it was considered necessary to compile a hydrogeological map at a scale of 1: 50.000. Indicative information with local character is given, while simple points of observation were also illustrated. Special effort was made in the recognition of places where high water level is expected affecting the foundation of common structures.

\subsection{Tectonic map}

A tectonic map of Athens Prefecture region was drawn at a scale of 1:50.000, in order to:

a) Show the main tectonic lines and trends that characterize the structure of the studied region.

b) Point out the areas where the geological formations are generally influenced by tectonics and probably appear differentiated geotechnical behaviour

It is noted that tectonic lines, drawn in the tectonic map, were indentified by at least two of the following ways:

- Field work

- Air photos interpretation

- Bibliographic reports and maps

\subsection{Earthquake epicenters' map}

A map of seismic epicenters was compiled at a scale of 1:250.000 in order to sketch out the seismic potential of the wider area around the study region. This map illustrates the distribution of shocks with magnitudes $\geq 4 \mathrm{R}$ which occurred in the area around the city.

\section{Description of digital data}

For the compilation of the engineering geological map of Athens Prefecture area at a scale of 1:10.000 including eleven (11) A0 size sheets, the following thematic levels were created for the relative sort of data:

- Sheets' connection diagram

- Boundaries of Athens Prefecture area

- Boundaries of Municipalities and Communities

- Greek territory boundaries

- City sector

- Road network

- Boundaries of engineering geological units

- Borehole's point

- Photo's point

- Underground water level 
- Local underground water level

- Faults

The topographic contours (40 m interval) exported in raster format, originate from the vector digital data of the Hellenic Military Geographical Service. The thematic levels referring to the built environment (roads etc) were created from the digital data provided by the Prefecture of Athens, while further digital data used for the needs of the project originate from other sources such as the University of Patras and the Hellenic Mapping and Cadastral Organization.

The points illustrating either boreholes' or photos' sites are connected through hyperlink to relative picture files (Log records and Photos).

Two hundreds forty five (245) borehole points, were imported in the data base and marked on the map. They were selected after the evaluation of more than 2000 borehole records and considered to be most reliable and representative. They are well distributed over the map area and the different geological formations and originate from the Institute of Geology and Mineral Exploration, the Water Company of Athens, the Ministry of Environment and Public Works, the Prefecture of Athens, the University of Patras, as well as private companies.

Moreover five hundreds twelve (512) points, corresponding to photos taken during the recent field work, were marked on the map and imported in the data base.

In addition, for the compilation of the Earthquake epicenters' thematic map, digital data concerning earthquake epicenters of the wider region of Attiki were imported in the database. These data were obtained by Comninakis, P. - Papazachos, B. (1986) catalogue, up to 1949 and from the Geodynamic Institute of Athens Observatory records, for the time period $1950-2005$.

\section{Acknowledgments}

The authors of the present article wish to thank Siemos N., Galanakis D. and Mourtas D. for the excellent cooperation.

\section{References}

Andronopoulos, V., Koukis, G. 1976. Geological - Geotechnical study of Athens Acropolis region, Athens, Institute of Geology and Mineral Exploration, Geotechnical Researches, No 1.

Anon., 1981. Rock and Soil description for Engineering Geological mapping, Bulletin of I.A.E.G, 24, Report by the Commission of Engineering Geological Mapping.

Comninakis, P.E., Papazachos, B.C., 1986. A catalogue of earthquakes in Greece and surrounding area for the period 1901-1985. Thessaloniki, University Publications 1, Geophysical Laboratory, $167 \mathrm{pp}$.

Dearman, W.R., Matula, M. 1976: Environmental aspects of Eng. Geological Mapping. Bulletin of I.A.E.G., 14, 141-146.

Dounas A., Kallergis G., Morfis A., 1976. Hydrogeological research for the Athens Metro study. Athens, Institute of Geology and Mineral Exploration.

EPPO, 2000. Greek Seismic Regulation (and modifications)

Gaitanakis, P. 1982. Geological map “Athinai - Piraeus”, scale 1:50.000, Athens, Institute of Geology and Mineral Exploration.

Galanopoylos, A., 1989. The seismic danger in major and minor Attica region. Athens, Proceedings of Athens Academy, 63, 1st (1988). 
Kakkavas, N., Gioni-Stauropoulou, G. 1978. Hydrogeological study of Peristeri Municipality, Attica. Problems of groundwater level uplift, Athens, Institute of Geology and Mineral Exploration, Researches No 23 ,18pp.

Katsikatsos G., 2002. Geological map “Athinai - Elefsis”, scale 1:50.000, Athens, Institute of Geology and Mineral Exploration.

Katsikatsos, G., Mettos, A., Vidakis, M., Dounas, A. 1983. Geological map “Athinai - Elefsis”, scale 1:50.000, Athens, Institute of Geology and Mineral Exploration.

Katsikatsos, G., Migiros, G., Triantaphyllis M., Mettos A. 1986. Geological structure of internal Hellenides. Athens, Institute of Geology and Mineral Exploration, Geol. and Geoph. Researches, 191-212.

Koukis, G., Sabatakakis, N. 2000. "Engineering geological environment of Athens, Greece". Bulletin of Engineering Geology and the Environment, 59: 127 - 135

Kounis G., 1980. Hyydrogeological conditions of the region of Solar Village, No 3, (Lykovrysi), Athens, Institute of Geology and Mineral Exploration.

Kounis G., 1981. Hydrogeological research for Athens Metro, Hydrogeological conditions Analysis II, Athens, Institute of Geology and Mineral Exploration.

Kynigalaki, M., Nikolaou, N., Karfakis, J., Koutsouveli, An., Poyiadji, El., Pyrgiotis, L., Konstantopoulou, G., Apostolidis, Em., Bellas, M., Loupasakis, K., Spanou, N., Siemos, N., Galanakis, D. and Mourtas, D. 2006. Engineering geological map of Athens Prefecture region, at 1: 10.000 scale, with relative data base and Atlas of thematic maps, Athens, Institute of Geology and Mineral Exploration.

Kynigalaki, M., Rozos, D., Vakondios, 2001. Seismic zonation study in the region of Anthoupolis, Peristeri Municipality. Athens, Institute of Geology and Mineral Exploration.

Latsoudas, X. 2003. Geological map “Koropi - Plaka”, scale 1:50.000, Athens, Institute of Geology and Mineral Exploration.

Marinos, P., Bouckovalas, G., Tsiambaos, G., Sabatakakis, N., Antoniou, A. (2001), “Ground zoning against seismic hazard in Athens, Greece”, Engineering Geology, 62: 343 - 356

Mettos, A.,1992. Geological and Paleogeographical study of terrestrial Neogene and Quaternary of formations of northeastern Attica and southeastern Viotia. Athens, PhD Thesis, Athens University.

Mouyiaris N., Andronopoylos V., et.al., 1989. Seismotectonic map of Greece, scale 1:500.000, Athens. Institute of Geology and Mineral Exploration.

Mouyiaris N., 1994. Seismic history of Aegea region (2400 B.C. - 1900 A.D.). Patras, PhD Thesis. Patras University.

Papadeas, G. 2002. Geological researches in Attica, Athens, Athens University.

Papanikolaou, D., 1986. Geology of Greece. Athens, Pentalofos Publications.

Pian De, A. 1949. Aperche de la Mine de Peristeri, Athens, 12 pp.

Report of the Commission of Engineering Geology Mapping, of the IAEG, 1979. Rock and Soil materials, Classification of rocks and soils for Engineering Geological Mapping. Part I: Rock and Soil Materials. Bulletin of I.A.E.G., 19, Krefeld, 364-371.

Rozos, D., Vakondios, I., Kynigalaki, M., Argyris, Ch., 1999. Geotechnical Study of subsidence phenomena in Anthoupoli, Peristeri Municipality, Athens, Institute of Geology and Mineral Exploration.

Sabatakakis N., 1991. Engineering geological research of Athens Basin, PhD Thesis. Patras. Patras University. 
Siemos, N., Charmanidis, F., 2003. Hydrogeological - Drilling research of Olympic Works regions (Chaidari, Korydallos, Nikaia), Athens, Institute of Geology and Mineral Exploration.

Siemos, N., Charmanidis, F., 2003. Hydrogeological - Drilling research of Olympic Works regions (Pedion Areos), Athens, Institute of Geology and Mineral Exploration.

Siemos, N., Charmanidis, F., 2003. Hydrogeological - Drilling research of Olympic Works regions (OAKA, Markopoulo, Elliniko, Kallithea - Faliron), Athens, Institute of Geology and Mineral Exploration.

Siemos, N., Charmanidis, F., 2003. Hydrogeological - Drilling research of Olympic Works regions (Ethnikos Kipos), Athens, Institute of Geology and Mineral Exploration.

Trikalinos, I., Mousoulos, A. 1949. Coal mines of Peristeri, Athens, 34pp.

UNESCO/IAEG 1976. Engineering geological maps. A guide to their preparation, Paris, UNESCO Press, $79 \mathrm{pp}$.

Voreadis, G. 1940. The lignite mines of Athens basin, Athens. 